\title{
SEMIOTIK LAMBANG EMOJI \\ PADA STATUS DAN KOMENTAR FACEBOOK MAHASISWA PENDIDIKAN BAHASA INDONESIA
}

\author{
Anin Asnidar \\ aninasnidar.pose@yahoo.com
}

\begin{abstract}
Abstrak
Semiotik adalah ilmu yang mengkaji tanda sebagai bagian dari kehidupan sosial. Ferdinand de Saussure dikutip Piliang (2003:256) Secara implisit dalam definisi Saussure ada prinsip bahwa semiotika sangat menyandarkan dirinya pada aturan main (rule) atau kode sosial (social code) yang berlaku di dalam masyarakat sehingga tanda dapat dipahami maknanya secara kolektif. Eksistensi semiotika Saussure adalah relasi antara penanda dan petanda berdasarkan konvensi, biasa disebut dengan signifikasi. Semiotika signifikasi adalah sistem tanda yang mempelajari relasi elemen tanda dalam sebuah sistem berdasarkan aturan atau konvensi tertentu. Konvensi sosial diperlukan untuk memaknai tanda. Dalam berkomunikasi, seseorang menggunakan tanda untuk mengirim makna tentang objek dan orang lain akan menginterpretasikan tanda tersebut. Komunikasi dipahami sebagai proses manusia merespon perilaku simbolik dari orang lain (Adler \& Rodman, 2010: 4). Bahasa, kata, gesture, tanda, merupakan bagian dari simbol yang digunakan manusia dalam mendefinisikan sesuatu atau menyampaikan sesuatu ke orang lain.

Facebook adalah salah satu dari sekian banyak sosial media atau situs jejaring sosial yang ada di jagad web. Tulisan ini membahas tentang semiotik lambang emoji pada facebook, yaitu lambang emoji pada status dan komentar facebook mahasiswa jurusan Pendidikan Bahasa Indonesia. Penggunaan lambang emoji pada status dan komentar facebook cenderung tidak sesuai dengan makna lambang emoji yang sebenarnya, sehingga memunculkan konflik antara pengguna facebook. Peneliti menggunakan data berupa dokumentasi komentar dan status di facebook mahasiswa jurusan Pendidikan Bahasa Indonesia. Dokumentasi dilakukan dengan cara mengambil screenshoot dari status dan komentar di faceebook. Dalam status dan komentar tersebut diharuskan ada lambang emoji yang relevan dengan penelitian. Analisis data menggunakan analisis semiotika Saussure. Dari penelitian yang dilakukan ditemukan adanya perbedaan makna dalam lambang-lambang emoji pada status dan komentar mahasiswa jurusan Pendidikan Bahasa Indonesia. Penggunaan emoji pada status, dan komentar berdasarkan pada up date status pengguna lain atau berdasarkan keinginan pemberi komentar, tanpa mengetahui makna emoji yang sebenarnya. Makna suatu emoji dapat berbeda tergantung dari status facebook yang menyertainya. Selain itu faktor eksternal seperti konteks sosial, agama, budaya, dan sebagainya. Sebuah kelompok kecil mampu untuk membuat makna tersendiri dari suatu lambang emoji, tergantung dari kesepakatan anggota dalam kelompok tersebut.
\end{abstract}

Kata kunci: facebook, emoji, semiotik. 


\section{Pendahuluan}

Makhluk hidup tidak terlepas dari sebuah tanda. Mereka berusaha menampilkan sesuatu untuk dapat dipahami oleh orang lain. Sebagai manusia, kita melakukan hubungan dan interaksi dengan cara sendiri yang penuh dengan keragaman namun kadang-kadang apa yang dipaparkan belum mampu dipahami oleh orang lain. Tanda, sebagai alat komunikasi memerlukan konsep yang sama agar bisa dipahami. Tapi, pada kenyataannya tidak demikian karena manusia memiliki daya interpretasi yang berbeda.

Kehidupan manusia tidak terlepas dari aktivitas komunikasi karena komunikasi merupakan bagian integral dari sistem dan tatanan kehidupan sosial manusia dan masyarakat. Aktivitas komunikasi dapat dilihat pada setiap aspek kehidupan sehari-hari manusia yaitu sejak dari bangun tidur sampai manusia beranjak tidur pada malam hari. Bisa dipastikan sebagian besar dari kegiatan kehidupan kita mengunakan komunikasi baik komunikasi verbal maupun nonverbal.

Dalam kajian komunikasi, semiotika merupakan ilmu penting, sebab tandatanda merupakan basis utama dari seluruh komunikasi. Dengan tanda-tanda manusia dapat melakukan komunikasi apapun dengan sesamanya. Dalam perkembangannya, kajian semiotika berkembang kepada dua klasifikasi utama, yakni semiotika komunikasi dan semiotika signifikasi. Semiotika komunikasi menekankan pada teori tentang produksi tanda yang salah satu di antaranya mengasumsikan adanya 5 faktor dalam komunikasi (pengirim, penerima, pesan, saluran dan acuan). Sedangkan semiotika signifikasi memberikan tekanan pada teori tanda dan pemahamannya dalam suatu konteks tertentu. Jika diterapkan pada tanda-tanda bahasa, maka huruf, kata, kalimat, tidak mempunyai arti apa-apa dalam komunikasi.

Teori Semiotik ini dikemukakan oleh Ferdinand De Saussure (1857-1913). Dalam teori ini semiotik dibagi menjadi dua bagian (dikotomi) yaitu penanda (signifier) dan pertanda (signified). Penanda dilihat sebagai bentuk/wujud fisik dapat dikenal melalui wujud karya arsitektur, sedang pertanda dilihat sebagai makna yang terungkap melalui konsep, fungsi dan/atau nilai-nlai yang terkandung didalam karya arsitektur. Eksistensi semiotika Saussure adalah relasi antara penanda dan petanda 
berdasarkan konvensi, biasa disebut dengan signifikasi. Semiotika signifikasi adalah sistem tanda yang mempelajari relasi elemen tanda dalam sebuah sistem berdasarkan aturan atau konvensi tertentu. Kesepakatan sosial diperlukan untuk dapat memaknai tanda tersebut. Menurut Saussure, tanda terdiri dari: Bunyi-bunyian dan gambar, disebut signifier atau penanda, dan konsep-konsep dari bunyi-bunyian dan gambar, disebut signified.

Kemajuan teknologi menghasilkan sebuah teori Computer Mediated Communication. Computer Mediated Communication menurut A.F. Wood dan M.J. Smith adalah segala bentuk komunikasi antar individu, individu dengan kelompok, yang saling berinteraksi melalui komputer dalam suatu jaringan internet. CMC mempelajari bagaimana perilaku manusia dibentuk atau diubah melalui pertukaran informasi melalui media komputer. Salah satu contoh CMC adalah Facebook. Facebook merupakan jejaring sosial yang digemari saat ini. Situs web jejaring sosial populer ini diluncurkan pada 4 Februari 2004. Facebook didirikan oleh Mark Zuckerberg, seorang mahasiswa Harvard kelahiran 14 Mei 1984 dan mantan murid Ardsley High School. Pada awalnya situs jejaring sosial keanggotaannya masih dibatasi untuk mahasiswa dari Harvard College. Selanjutnya berkembang pada universitas lain dan meluas hingga ke Indonesia. Sejak 11 September 2006, orang dengan alamat surat-e apa pun dapat mendaftar di Facebook. Pengguna dapat memilih untuk bergabung dengan satu atau lebih jaringan yang tersedia, seperti berdasarkan sekolah, tempat kerja, atau wilayah geografis.

Sri Widowati, Country Director Facebook Indonesia, mengungkapkan bahwa angka pengguna aktif bulanan jejaring sosial tersebut hingga Oktober 2016 sudah mencapai angka 88 juta di Indonesia. Fitur hiburan dalam Facebook disebut aplikasi. Dengan aplikasi yang lebih lengkap dan praktis, masyarakat berangsurangsur beralih pada facebook. Facebook memiliki aplikasi beranda yang dengan mudah dapat dibaca oleh pengguna. Pengguna dengan mudah mengetahui apa yang sedang dipikirkan oleh pengguna lainnya. Lalu, terjadi interaksi diantara mereka dengan berkomentar baik dalam bentuk kata-kata atau hanya memberi like dan memberi berbagai macam emoji.

Emoji biasa digunakan pada layanan pesan singkat yang didukung dengan jaringan internet. Layanan pesan singkat ini pada dasarnya sama dengan sms, perbedaannya dari segi jaringan. Pada saat ini dapat dikatakan bahwa manusia lebih 
sering menggunakan layanan pesan singkat dibandingkan dengan sms. Hal ini terbukti dengan munculnya beragam sosial media dan layanan pesan instan (chatting) seperti Friendster, Facebook, Twitter, Instagram, Path, Line, WhatsApp, Yahoo Messenger, Blackberry Messenger, dan masih banyak lagi. Prinsip emoji yaitu untuk mengekspresian emosi maupun perasaan pengguna pesan singkat dalam penyampaian pesan kepada penerima pesan

Penggunaan emoji pada status, dan komentar berdasarkan pada up date status pengguna lain atau berdasarkan keinginan pemberi komentar, tanpa mengetahui makna emoji yang sebenarnya.

\section{Rumusan Masalah}

Berdasarkan latar belakang diatas penulis ingin mengetahui bagaimana emoji yang digunakan pada status dan komentar facebook oleh mahasiswa Jurusan Pendidikan Bahasa Indonesia. Penelitian ini diberi judul "Semiotik lambang Emoji pada Status dan Komentar Facebook Mahasiswa Jurusan Pendidikan Bahasa Indonesia."

\section{Teori}

\section{Semiotika Ferdinan de Saussure}

Mempelajari semiotika sastra berarti mempelajari ilmu kebahasaan yang tidak terlepas dari pemahaman masalah tanda-penanda. Hal ini terjadi karena sastra bermediumkan bahasa yang tidak mungkin dapat dihilangkan oleh pengarangnya.

Ferdinan de Saussure adalah seorang linguis berkebangsaan Swiss, peletak dasardasar kebahasaan sebagai sistem tanda. Melalui 4 dasar konsep tentang :

(1) penampang sinkronik dan diakronik, (2) relasi sintakmatik dan paradigmatik

(3) konsep tanda dan penanda, (4) pengertian antara bahasa (lingua) dan tuturan (parole) (Nurgiantoro, 2010:39).

Tokoh yang dianggap sebagai pendiri semiotik adalah dua orang yang tidak saling mengenal dan mempengaruhi, yaitu; Ferdinand de Saussure (1857-1913) seorang ahli linguistik dan Charles Sander Pierce (1839-1914) seorang ahli filsafat. Kedua sarjana tersebut menggunakan istilah yang berbeda. Saussure menggunakan istilah semiologi sedangkan Pierce menggunakan istilah semiotika, tetapi dalam perkembangan selanjutnya istilah semiotika yang populer. Pierce mengatakan bahwa semiotik merupakan paduan atau sinonim kata logika. 
Menurut Saussure, seperti dikutip Pradopo (1991:54) tanda adalah kesatuan dari dua bidang yang tidak dapat dipisahkan, seperti hanya selembar kertas. Dimana ada tanda, disana ada sistem. Artinya, sebuah tanda (berwujud kata atau gambar) mempunyai dua aspek yang ditangkap oleh Indra yang disebut dengan signified, bidang petanda atau konsep atau makna. Aspek kedua terkandung didalam aspek pertama. Jadi pertanda merupakan konsep atau apa yang dipresentasikan oleh aspek pertama.

Batasan yang lebih jelas kemudian dikemukakan Preminger (2011:89) "Semiotik adalah ilmu tentang tanda-tanda." Ilmu ini menganggap bahwa fenomena sosial atau masyarakat dan kebudayaan itu merupakan tanda-tanda. Semiotik mempelajari sistem, aturan-aturan, konvensi yang memungkinkan tanda-tanda tersebut mempunyai arti.

\section{Facebook}

Perkembangan globalisasi telah mendorong suatu modernisasi dalam dunia komunikasi. Pandangan masyarakat yang beranggapan bahwa komunikasi sangat penting pada masa kini, telah memancing suatu revolusi besar dalam perkembangan teknologi komunikasi. Hal tersebut terlihat dari banyaknya media yang digunakan dalam proses komunikasi.

Facebook sebagai salah satu unsur dari teknologi komunikasi, yaitu media penyalur dan penerima informasi adalah salah satu bentuk perkembangan teknologi dalam dunia komunikasi. Media komunikasi dan penyalur informasi yang dinilai cukup efektif untuk masa kini. Mudahnya penggunaan facebook yang memfasilitasi pengguna untuk bercerita berbagai hal, seperti kepentingan pribadi, ekonomi bahkan politik, berbagi informasi dan berkomunikasi tidak hanya satu pihak dalam satu wilayah, melainkan dengan pihak atau kelompok lain di belahan negara manapun, menjadikan lebih dari 600 juta pengguna aktif facebook di seluruh dunia tertarik menggunakan dan enggan untuk meninggalkan. Hal ini memungkinkan untuk membentuk kohesivitas masyarakat. Karena pengguna facebook akan berkomunikasi lebih efektif, bebas, terbuka dengan anggota pengguna atau kelompoknya, sehingga membuatnya semakin nyaman berada dengan anggota kelompok tersebut dan sulit untuk meninggalkannya.

Facebook adalah salah satu dari sekian banyak sosial media atau situs jejaring sosial yang ada di jagad web. Facebook melengkapi jejaring sosial yang telah ada sebelumnya seperti MIRC dan friendster. Aplikasi yang lebih lengkap dan praktis 
menybabkan masyarakat berangsur-angsur beralih pada facebook. Facebook memiliki aplikasi beranda yang dengan mudah dapat dibaca oleh pengguna. Pengguna dengan mudah mengetahui apa yang sedang dipikirkan oleh pengguna lainnya. Lalu, terjadi interaksi diantara mereka dengan saling berkomentar baik dengan kata-kata atau dengan lambang emoji dan emoticon atau stiker. Kita dengan mudah menemukan banyak teman dengan cara meng-add. Selain itu, Facebook juga menyuguhkan berbagai macam permainan. Peningkatan pesat pengguna Facebook di Indonesia dipicu oleh mudahnya penggunaan akses Facebook menggunakan telepon selular. Terutama yang sudah meletakkan fitur Facebook sebagai fitur standar atau favorit dari beberapa merk telepon selular. Fitur Facebook menjadi nilai jual tersendiri bagi para produsen telepon selular yang menjual produknya di Indonesia. Pengguna internet pemula mengakses Facebook lebih awal sebelum menggunakan fitur internet lainnya. Namun perlu disadari bahwa facebook dapat menimbukan dampak negatif, seperti kejahatan di dunia maya atau cyber crime yang dilakukan oleh oknum-oknum yang tidak bertanggungjawab dengan mengirimkan konten yang bersifat negative. Maka dari itu, pergunakan facebook secara efektif dan efisien. Jadikan diri sebagai smart user atau pengguna yang pintar dengan memilih kontenkonten yang bermanfaat bagi kehidupan dan berdampak positif dalam upaya meningkatkan kohesivitas masyarakat.

\section{Emoji}

Secara harfiah emoji berasal dari bahasa Jepang, " $e$ " yang berarti gambar dan "moji" yang berarti huruf. Dengan kata lain emoji merupakan ikon karakter dalam tulisan. Emoji diciptakan oleh Shigetaka Kurita pada tahun 1990. Beliau merupakan bagian dari tim yang mengerjakan sebuah platform Internet seluler milik NTT DoCoMo. Emoji pertama kali hanya berukuran 12 x 12 pixel. Tujuan awal munculnya emoji adalah untuk mengatasi salah paham yang terjadi dalam melakukan percakapan di media sosial, karena kesalahan menggunakan emoji bisa menimbulkan banyak akibat. Bagaimana jadinya jika seharusnya menggunakan emoji menangis, tapi ternyata menggunakan emoji kecewa? Hal itu jelas akan menimbulkan konflik. Gambar emoji hampir sama, tapi berbeda makna, kadangkadang disalahartikan oleh pengguna media sosial. Prinsip emoji yaitu untuk mengekspresikan emosi maupun perasaan pengguna pesan singkat dalam penyampaian pesan kepada penerima pesan.

Tidak berbeda dengan ikon karakter lainnya seperti kaomoji dan emoticon, 
emoji merupakan simbol bergambar yang menyerupai ekspresi wajah manusia, hewan, kegiatan, hari libur.

Emoji dapat menunjukan cara bagaimana pesan disampaikan, dengan indikator sebagai berikut, yaitu indikator perasaan, indikator nonverbal, dan indikator ilokusi. Ketika disisipkan pada suatu kelimat emoji berfungsi sebagai aspek kebahasaan yang menunjukan cara bagaimana suatu pesan disampaikan. Selain itu, emoji mempunyai fungsi lain untuk mengungkapkan perasaan komunikator kepada komunikan, bentuk simbolis dari simpati dan solidaritas yang ditunjukan oleh komunikator dalam pesan yang disampaikan, memperhalus kritikan, menegaskan landasan pembicaraan, dan menyamarkan maksud dari pesan yang dikirim oleh komunikator. Selain itu, menurut Stark dan Crawford dalam webnya menuturkan bahwa emoji juga dapat berperan sebagai:

a) Pictogram: simbol yang mewakili benda-benda konkrit.

b) Ideogram: simbol yang mewakili konsep atau gagasan mengenai sesuatu.

c) Emoticon: simbol yang mewakili perasaan.

d) Phatic expression: ungkapan untuk mengadakan atau memelihara kontak antara komunikator dan komunikan.

Emoji digunakan pada layanan pesan singkat yang didukung dengan jaringan internet. Layanan pesan singkat ini pada dasarnya sama dengan sms, perbedaannya dari segi jaringan. Pada saat ini dapat dikatakan bahwa manusia lebih sering menggunakan layanan pesan singkat dibandingkan dengan sms.

\section{Jenis-Jenis Emoji}

a. Smiley

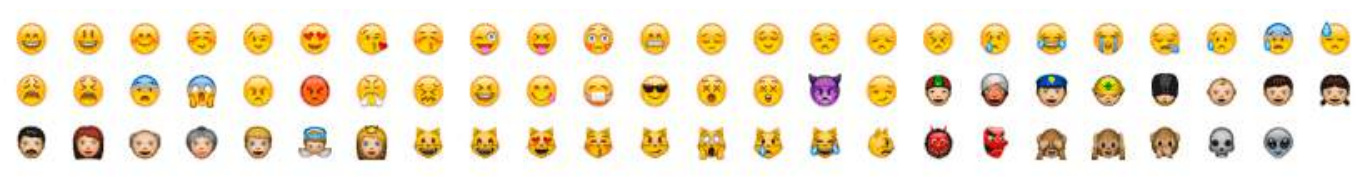

b. Wajah dan Orang

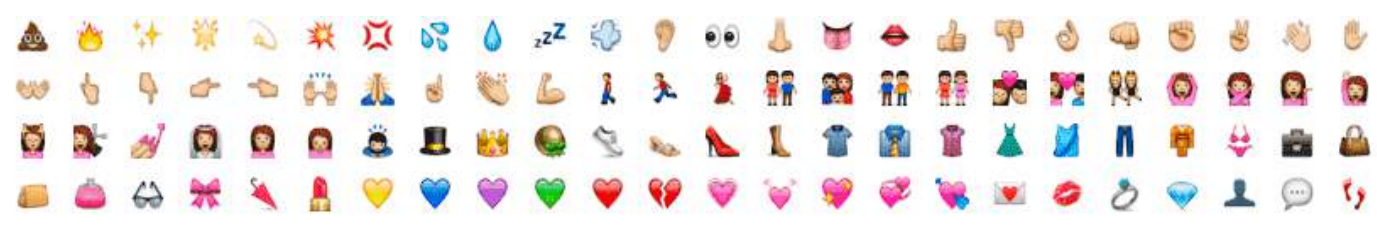


c. Binatang dan tumbuhan

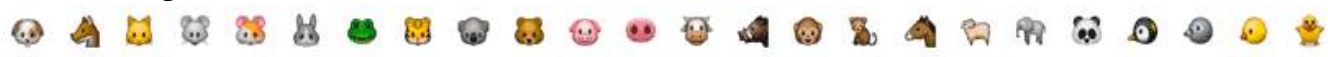

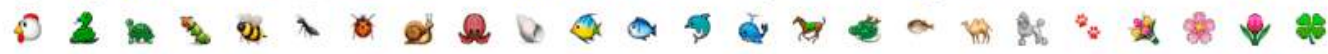

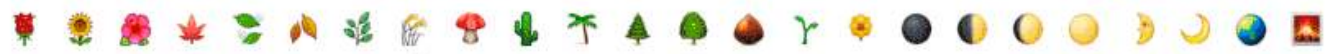

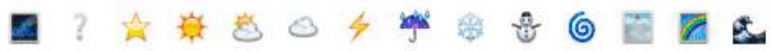

e. Objek

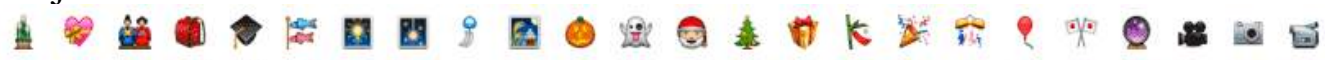

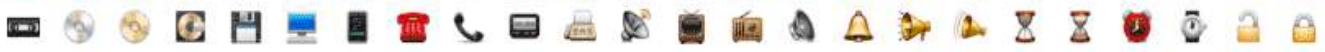

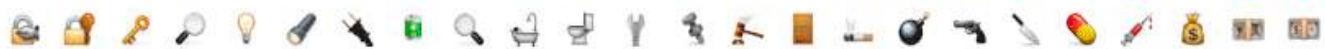

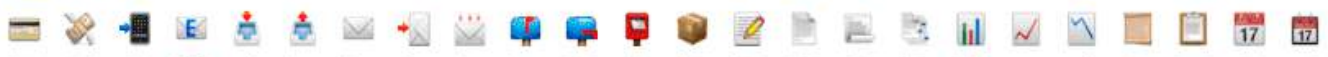

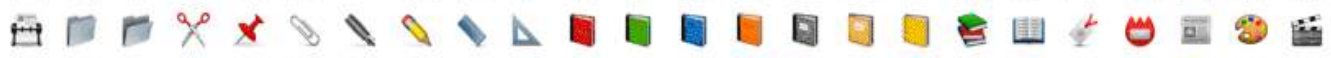

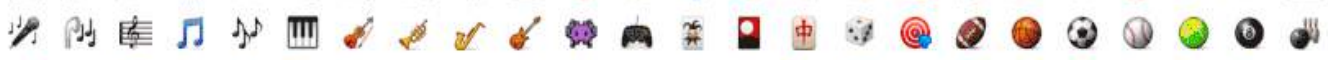
¿*IN

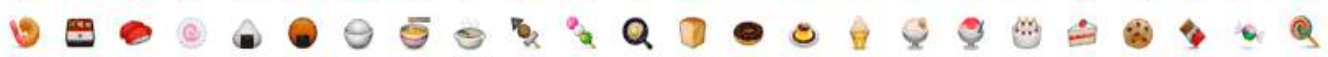
0000050000 is i \& 000

f. Simbol

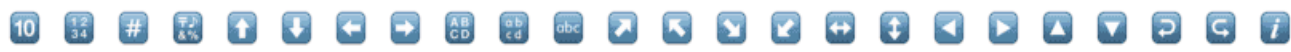

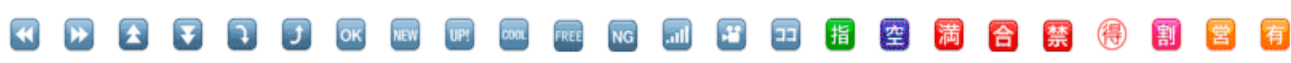

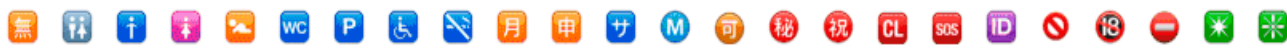
×

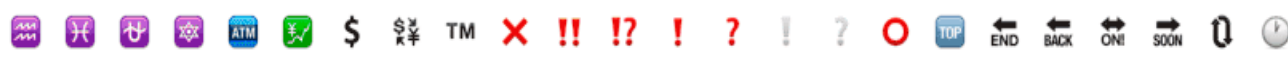

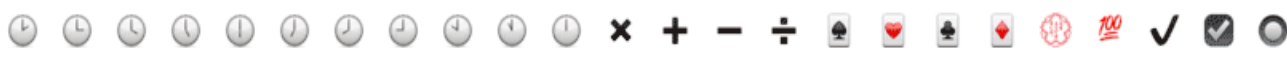

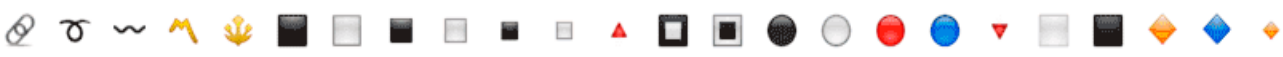




\section{Pembahasan}

\section{Hasil Analisis Emoji pada Status dan Komentar Facebook}

Berdasarkan hasil analisis lambang emoji pada status dan komentar facebook mahasiswa Jurusan pendidikan Bahasa Indonesia ditemukan bahwa ternyata hampir semua emoji digunakan dalam membuat status dan komentar. Status dan komentar pada facebook menyatakan makna: doa, sindiran, keluhan atau kekecewaan, promosi, protes sosial, pemberian semangat, imbauan, pengumuman, kelakar, renungan dan menggunakan bentuk singkatan yang berupa penyingkatan kata, penyingkatan huruf awal kata, penyingkatan akhiran, penyingkatan salam, penyingkatan kata ulang, akronim, bahasa alay, ungkapan. Penulis status dan komentar menggunakan ragam formal dan nonformal.

Emoji yang sering digunakan oleh mahasiswa adalah emoji bahagia, gugup, tertarik, tertawa sambil menangis, bahagia dengan mata tersenyum, tertawa kecil, tertawa sampai berkeringat, tertawa, malaikat, berkedip/genit, tersenyum, tersenyum puas, muka memerah, wajah bodoh, senyum terbalik, jatuh cinta, memberikan ciuman, gila, muka uang, memeluk, berpikir, muka sedih, muka khawatir, muka marah, sangat marah, mengerutkan dahi, sedih kecil, tidak bahagia, muka penat, berteriak dalam ketakutan, terkejut, takut, prihatin, tersakiti, muka stres, kelelahan, muka ngantuk, tutup mulut, muka masker, sakit, terluka, tidur, setan bahagia, setan terluka, selebrasi, tepuk tangan, sampai jumpa, memberi jempol, kepalan tangan, memberi jempol ke bawah, kepalan tangan ke atas, perdamaian, ok, stop, tangan terbuka, melenturkan otot, memohon, menunjuk ke atas, jari tengah, sapaan, muka heran, muka pusing tujuh keliling.

Penggunaan emoji mahasiswa Jurusan Pendidikan Bahasa Indonesia tidak memperhatikan makna yang terkandung di balik emoji yang dimunculkan. Mereka hanya menggunakan emoji berdasarkan gambar tanpa memperhatikan makna sasaran penggunaan lambang emoji. Emoji yang memiliki gambar yang hampir sama dianggap memiliki makna yang sama walaupun pada kenyataannya memiliki makna yang berbeda. Hal itu terlihat dari komentar yang menggunakan emoji yang tidak sesuai dengan status. Pengguna emoji, khususnya mahasiswa Jurusan Pendidikan Bahasa dan Sastra Indonesia tidak menyadari bahwa penggunaan emoji dapat menggambarkan karakter penggunanya. Karakter pengguna facebook dapat dilihat dari isi komentar dan penggunaan kata-kata dalam update status yang menggunakan emoji. 
Contoh emoji yang sering dipertukarkan :

(gugup) $\bigoplus^{A}($ tertarik) $\rightarrow$ kedua emoji tersebut sering diartikan "tertawa"

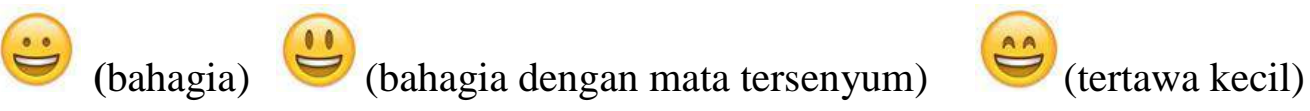

Ketiga emoji di atas digunakan untuk memberi komentar "tertawa"

(1)

(malaikat) $\rightarrow$ Lambang emoji ini digunakan mahasiswa untuk menyatakan rasa senang (gembira.)

(kelelahan) $\rightarrow$ Lambang emoji ini digunakan mahasiswa untuk menyatakan sakit influenza.

$\because$ (muka stress)

$\Theta_{\text {(wajah bodoh) }}$ (gila) $_{\text {(tertawa sambil mengeluarkan lidah) }}$

(bermuka tebal)

Keempat emoji ini sering digunakan oleh mahasiswa untuk memberi komentar mengejek

(jatuh cinta) $\rightarrow$ Lambang emoji ini digunakan ketika mahasiswa merasa senang dengan suatu hal, tanpa memperhatihan jenis kelamin teman chatting.

$\bigodot_{\text {(sedih kecil) }} \bigodot_{\text {(tidak bahagia) }} \bigodot_{\text {(muka khawatir })} \because_{\text {(bingung) }}$

Keempat emoji di atas sering digunakan untuk memberi komentar sedih

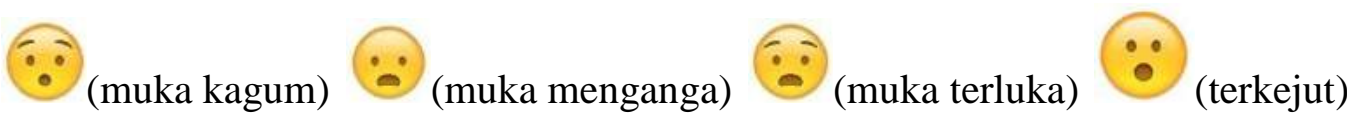

Keempat emoji di atas sering digunakan untuk memberi komentar terkejut

(sapaan) $\rightarrow$ lambang emoji ini digunakan oleh mahasiswa untuk mengucapkan selamat tinggal.

(berteriak dalam ketakutan) Lambang emoji ini digunakan oleh mahasiswa ketika sangat kaget.

(menunjukkan kebahagiaan atau perayaan atas sebuah kesuksesan (hore))

Lambang emoji ini digunakan oleh mahasiswa untuk mengatakan menyerah. 
(play boy)

Lambang emoji ini digunakan oleh mahasiswa untuk menyatakan kegembiraan.

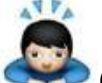

(menunjukkan rasa hormat) Lambang ini diartikan sedang berpikir.

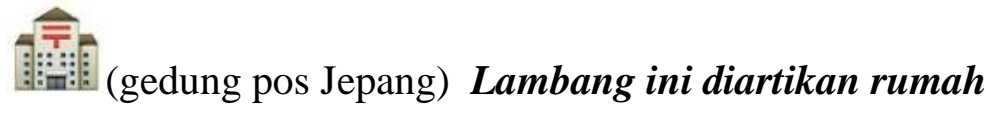




\section{Penutup}

Status dan komentar pada facebook menyatakan makna: doa, kegembiraan, sindiran, keluhan atau kekecewaan, promosi, protes sosial, pemberian semangat, imbauan, pengumuman, kelakar, renungan dan menggunakan bentuk singkatan yang berupa penyingkatan kata, penyingkatan huruf awal kata, penyingkatan akhiran, penyingkatan salam, penyingkatan kata ulang, akronim, bahasa alay, ungkapan. Penulis status dan komentar menggunakan ragam formal dan nonformal.

Penggunaan emoji pada status dan komentar di facebook tidak memperhatikan makna yang terkandung di balik emoji yang dimunculkan. Pengguna hanya berdasarkan gambar tanpa memperhatikan makna sasaran penggunaan lambang emoji.

Penggunaan emoji pada status dan komentar di facebook dipengaruhi beberapa faktor, antara lain: sosial, tingkat pendidikan, usia, jenis kelamin, topik yang disampaikan, dan tujuan yang hendak dicapai. Hal tersebut terjadi karena facebooker berasal dari berbagai wilayah dengan status sosial, tingkat pendidikan, dan usia yang berbeda-beda. 


\section{DAFTAR PUSTAKA}

Atmadjaja, Jolanda Srisusana. 2003. Estetika Bentuk sebagai Pendekatan Semiotika pada Penelitian Arsitektur.

Danesi, Marcel. (2012). Pesan, Tanda, dan Makna. Yogyakarta: Jalasutra.

Halliday, M.A.K. 1992. Bahasa, Konteks, dan Teks: Aspek-aspek Bahasa dalam Pandangan Semiotik Sosial. Terjemahan Asruddin Barori Tou. 1985. Language, Context, and Text: Aspects of Language in A Social Semiotic Perspective. Victoria: Deakin University.

Hoed, Benni H. 2002. Strukturalisme, Pragmatik, dan Semiotik dalam Kajian Indonesia: Tanda yang Retak. Jakarta: Wedatama Widya Sastra.

Huda, Dian Patria Alan. 2017. Motivasi Penggunaan Emoji pada Whatsapp dan Kepuasan dalam penyampaian pesan.

Ibrahim, Idi Subandi. 2009. Komunikasi Empatik. Bandung : Pustaka Bumi Quraisy

Mahmudi. 2013. Penuntun Penulisan Karangan Ilmiah Untuk Mahasiswa, Guru dan Umum. Yogyakarta:Aswaja Pressindo.

Pradopo, Rachmat Djoko. 2012. Semiotika: teori, metode, dan penerapannya dalam pemaknaan sastra. Jurnal Humaniora 11.1 76-84.

R. Kunjana. 2010. Sosiolinguistik, Kode dan Alih Kode. Yogyakarta: Pustaka Pelajar.

Sobur, alex. 2006. Semiotika Komunikasi. Bandung: Remaja Rosdakarya

Slavin, R.E. 1997. Educational Psychologi Theory, Research, and Practise. Fourth Edition. Massachusetts: Allyn and Bacon Publishers.

Tarigan, Henry Guntur. 2008. Menulis sebagai Suatu Keterampilan Berbahasa. Bandung:Angkasa.

Tian, Ye, et al. 2017. Facebook Sentiment: Reactions and Emojis. Social NLP.

Tinarbuko, Sumbo. 2009. Semiotika Komunikasi Visual (Edisi Revisi). Yogyakarta: Jalasutra.

Sari, Yuita Arum, et al. 2014. User Emotion Identification In Twitter Using Specific Features: Hashtag, Emoji , Emoticon, and Adjective Term. Jurnal Ilmu Komputer dan Informasi. 
$+2$ 
$+2$ 